\title{
In Vitro Cell Injury by Oxidized Low Density Lipoprotein Involves Lipid Hydroperoxide-induced Formation of Alkoxyl, Lipid, and Peroxyl Radicals
}

Michael D. Coffey, Richard A. Cole, Scott M. Colles, and Guy M. Chisolm

Department of Cell Biology, Research Institute of The Cleveland Clinic Foundation, Cleveland, Ohio 44195

\begin{abstract}
Mounting evidence supports current theories linking lipoprotein oxidation to atherosclerosis. We sought the cellular biochemical mechanism by which oxidized LDL inflicts cell injury. Inhibitors of candidate pathways of cell death were used to treat human fibroblast target cells exposed to oxidized LDL. Ebselen, which degrades lipid hydroperoxides, inhibited oxidized LDL toxicity, consistent with our recent report that $7 \beta$-hydroperoxycholesterol $(7 \beta-O O H$ chol) is the major cytotoxin of oxidized LDL. Intracellular chelation of metal ions inhibited, while preloading cells with iron enhanced, toxicity. Inhibition of oxidized LDL and 7ß-OOH chol toxicity by 2-keto-4-thiolmethyl butyric acid, a putative alkoxyl radical scavenger and by vitamin $\mathrm{E}$, probucol and diphenylphenylenediamine, putative scavengers of peroxyl radicals was consistent with the involvement of these radicals in the lethal sequence. Cell death was thus postulated to occur due to lipid peroxidation via a sequence involving lipid hydroperoxide-induced, iron-mediated formation of alkoxyl, lipid, and peroxyl radicals. Pathways involving other reactive oxygen species, new protein synthesis, or altered cholesterol metabolism were considered less likely, since putative inhibitors failed to lessen toxicity. Understanding the mechanism of cell injury by oxidized LDL and its toxic moiety, $7 \beta-O O H$ chol, may indicate specific interventions in the cell injury believed to accompany vascular lesion development. (J. Clin. Invest. 1995. 96:1866-1873.) Key words: cytotoxicity $\bullet$ free radicals $\bullet$ cholesterol hydroperoxide $\bullet$ atherosclerosis • oxidized low density lipoprotein
\end{abstract}

\section{Introduction}

There is growing circumstantial evidence that oxidation of LDL is linked to the risk of atherosclerosis $(1,2)$. In vitro, oxidized LDL markedly alters the function of vascular cells, monocytes and macrophages (3). In addition, oxidized LDL has been found to be present in atherosclerotic lesions (4).

Oxidized LDL has also been shown to be toxic to vascular cells in vitro (5-8) and it has been hypothesized that this toxicity may be a factor in lesion development (9-11). We and others have studied aspects of oxidized LDL induced cytotoxic-

Address correspondence to Guy M. Chisolm, Ph.D., Department of Cell Biology, Cleveland Clinic Foundation, NC10, 9500 Euclid Avenue, Cleveland, OH 44195. Phone: 216-444-5854; FAX: 216-444-9404.

Received for publication 8 August 1994 and accepted in revised form 29 June 1995.

J. Clin. Invest.

(C) The American Society for Clinical Investigation, Inc. $0021-9738 / 95 / 10 / 1866 / 08 \quad \$ 2.00$

Volume 96, October 1995, 1866-1873 ity in certain cell systems using various preparations of oxidized LDL. Oxidized LDL toxicity does not appear to be cell specific $(5,6,12)$, nor does it require LDL receptors $(13,14)$. An association between fibroblasts passing through DNA synthesis phase (S-phase) and vulnerability to oxidized LDL induced cell death has been established (15). In a recent study we identified the most potent toxic fraction of oxidized LDL as $7 \beta$-hydroperoxycholesterol $(7 \beta-\mathrm{OOH} \mathrm{chol})$ and showed the presence of this oxysterol in human carotid atherosclerotic lesions (16). The toxicity of oxidized LDL to vascular cells could theoretically play a role in atherosclerotic lesion development. The mechanism by which oxidized LDL is cytotoxic remains unknown.

A better understanding of the mechanism involved in oxidized LDL induced cytotoxicity will make it possible to study whether oxidized LDL injures cells in vivo and to tailor a clinically relevant therapeutic approach against oxidized LDL induced cell injury. Hence, we employed a pharmacological approach using various antioxidants, radical scavengers, chelators, and enzyme inhibitors to discern the intracellular intermediates involved in the mechanism of oxidized LDL-induced cytotoxicity.

\section{Methods}

Materials. $N, N^{\prime}$-diphenyl-1,4-phenylene-diamine (DPPD), ${ }^{1}$ DMSO and 1,10-phenanthroline were purchased from Aldrich Chemical Co. (Milwaukee, WI). Reduced glutathione and cholesterol were obtained from Boehringer Mannheim (Indianapolis, IN). Desferal came from Ciba Geigy (Basle, Switzerland). Ebselen was a generous gift from Dr. Alex Sevanian (University of Southern California) or purchased from Cayman Chemical (Ann Arbor, MI). $\left[8-{ }^{14} \mathrm{C}\right]$ adenine $(46-60 \mathrm{mCi} /$ mmol $),\left[\right.$ Methyl- $\left.{ }^{3} \mathrm{H}\right]$ thymidine $(6.7 \mathrm{mCi} / \mathrm{mmol}),\left[{ }^{3} \mathrm{H}\right]$ leucine, $\mathrm{ICl}$ and ${ }^{125} \mathrm{I}(\sim 17 \mathrm{Ci} / \mathrm{mg}$ ) were obtained from ICN (Irvine, CA ). EDTA, acetonitrile, isopropanol, hexane, ethanol, acetone, methanol, and chloroform were purchased from Fisher Scientific. Dulbecco's modified essential medium (DME) was purchased from Whittaker Bioproducts (Walkersville, MD). A mixture of equal parts of DME and Ham's F12 (DME/ F12) was purchased from Irvine Scientific (Irvine, CA). Probucol was a generous gift from Marion Merrell Dow Pharmaceuticals (Cincinnati, $\mathrm{OH}$ ). EGF was obtained from Clonetics (San Diego, CA). All other reagents came from Sigma Chemical Co. (St. Louis, MO).

Lipoproteins. LDL (1.019 grams/ml $\leq$ solvent density $\leq 1.063$ grams $/ \mathrm{ml}$ ) was prepared by sequential centrifugation from pooled, citrated human plasma according to a modification (15) of the method of Hatch and Lees (17). Total cholesterol (Boehringer Mannheim Diagnostics kit No. 236691 with standards from Sigma No. C0248 or No.

1. Abbreviations used in this paper: Desferal, Desferrioxamine mesylate; DPPD, $N, N^{\prime}$-diphenyl-1,4-phenylene diamine; DTPA, diethylenetriamine pentaacetic acid; ETYA, eiosatetraynoic acid, HPLC, high performance liquid chromotography; KTBA, 2-keto-4-thiolmethyl butyric acid; LPDS, lipoprotein deficient serum; SOD-PEG, superoxide dismutase-polyethylene glycol; Tiron, 4,5-dihydroxy-1,3-benzene disulfonic acid. 
A2034), total protein (18), endotoxin (Whittaker Bioproducts kit No. QCL-1000), oxidation (thiobarbituric acid reactivity) $(15,19)$ and relative electrophoretic mobility (Corning) were assessed.

Lipoprotein deficient serum (LPDS, $d>1.25$ grams $/ \mathrm{ml}$ ) was prepared using a single ultracentrifugation step as previously described by Kosugi et al (15). LDL and LPDS were dialyzed against and maintained in isotonic saline, $0.5 \mathrm{mM}$ EDTA, $\mathrm{pH}$ above 8.2. Numerous preparations of LDL and LPDS were used in this study.

Oxidized LDL was prepared by dialyzing native LDL against $>100$ volumes isotonic saline ( $\mathrm{pH} 7-8$ ) containing 2-6 $\mu \mathrm{M} \mathrm{CuSO}_{4}$ until the LDL progressed through a predictable color change, from golden to pale yellow to translucent without color. The dialysate was then changed to isotonic saline containing $0.5 \mathrm{mM}$ EDTA ( $\mathrm{pH} \mathrm{8-9)}$ and dialysis was continued with at least four changes of dialysate. We have used this method of oxidation extensively and have found the thiobarbituric acid reactivity to vary from 5 to $10 \mathrm{nmol}$ malondialdehyde (used as standard)/mg LDL cholesterol and the total lipid peroxide to vary from 190 to $1800 \mathrm{nmol} / \mathrm{mg}$ LDL cholesterol $(15,20,21)$. Numerous preparations of oxidized LDL were used in these studies. Each preparation was tested for toxicity to human foreskin fibroblasts. As previously reported toxicity among preparations varied widely; concentrations achieving half maximal toxicity ranged from $\sim 15$ to $300 \mu \mathrm{g}$ LDL $\mathrm{chol} / \mathrm{ml}$.

Cell cultures. Human dermal fibroblasts were obtained from neonatal foreskins as previously described (7). Cells from a single donor were used in any particular experiment. Cells from numerous donors were used throughout the study. Cells were maintained in DME/F12 supplemented with 5-10\% FBS, (Whittaker Bioproducts).

Cell synchronization and pretreatment. Cells were synchronized (except where noted) using a double thymidine block as previously described $(15,22)$. Subconfluent cultures of human foreskin fibroblasts (passage 2 through 7 ) were plated on 24- or 48-well tissue culture clusters (Costar, Cambridge, MA) in DME/F12 supplemented with $10 \%$ FBS and $2 \mathrm{mM}$ thymidine. After 16 to $24 \mathrm{~h}$, the cells were rinsed twice with media to remove the excess thymidine and fresh media with $10 \%$ FBS was added. After 9 to $11 \mathrm{~h}$, this media was removed and the cells rinsed twice with plain media. During the second $2 \mathrm{mM}$ thymidine block, various pretreatment media were added to the cells (DME, 4 $\mathrm{mg}$ protein $/ \mathrm{ml}$ LPDS, $100 \mathrm{ng} / \mathrm{ml} \mathrm{EGF}, 2 \mathrm{mM}$ thymidine, $0.2 \mu \mathrm{Ci} / \mathrm{ml}$ $\left[{ }^{14} \mathrm{C}\right]$ adenine, plus pretreatment compounds or controls, as indicated). In experiments in which $\left[{ }^{3} \mathrm{H}\right]$ thymidine incorporation into DNA was to be measured, the $2 \mathrm{mM}$ thymidine was replaced with hydroxyurea (2-4 mM) for the second block. Appropriate solvent controls were used in all cases in which pretreatment compounds were added in solvents other than DME. After $12 \mathrm{~h}$, the cells were washed twice with media and media containing lipoproteins was added (DME, $4 \mathrm{mg}$ protein/ml LPDS, $100 \mathrm{ng} / \mathrm{ml}$ EGF, plus lipoproteins ). $20 \mathrm{~h}$ later the cells were assayed for cytotoxicity and cell survival.

Cell survival and cytotoxicity. For cell enumeration, cells were detached by trypsinization, diluted with isotonic saline, and counted using a Coulter Counter (Coulter Electronics Model ZM) as previously described $(6,7)$.

Release of ${ }^{14} \mathrm{C}$-labeled compounds into the media by cells preloaded with $\left[{ }^{14} \mathrm{C}\right]$ adenine was used as a measure of relative cell injury and/or death, as previously described (23). Toxicity in the wells was then calculated as the percent specific release of ${ }^{14} \mathrm{C}$-labeled compounds using Triton $\mathrm{X}-100$ released ${ }^{14} \mathrm{C}$ as $100 \%$ and ${ }^{14} \mathrm{C}$ released from control wells as $0 \%$.

HPLC isolation of $7 \beta-O O H$ chol. Aliquots of oxidized LDL containing up to $8 \mathrm{mg}$ total cholesterol were frozen $\left(-70^{\circ} \mathrm{C}\right)$ and lyophilized. Lipids were extracted with acetone three times and stored dry $\left(-70^{\circ} \mathrm{C}\right)$ under argon. The extracted lipids were resuspended in $1: 1$ (vol/vol) acetonitrile:isopropanol and separated by reverse phase preparative HPLC using a Waters $19 \mathrm{~mm} \times 15 \mathrm{~cm} \mu$ Bondapak $\mathrm{C} 18$ column and a water/acetonitrile/isopropanol gradient mobile phase as described previously (16). This was followed by further separation of the $7 \beta$ $\mathrm{OOH}$ chol-containing fraction using a $\mathrm{CN}$ column (Waters $3.9 \mathrm{~mm}$ $\times 300 \mu \mathrm{m} \mu$ Bondapak) and $3 \%$ isopropanol in hexane as isocratic sol- vent. We have previously shown this procedure to yield highly purified $7 \beta-\mathrm{OOH}$ chol (16).

$\left[{ }^{3} \mathrm{H}\right]$ Thymidine incorporation into DNA. Cells were incubated with $\left[{ }^{3} \mathrm{H}\right]$ thymidine $(1.0 \mu \mathrm{Ci} / \mathrm{ml})$ in culture media during selected experiments for various periods of time as indicated. At the end of the exposure period, the cell layers were rinsed twice with ice cold $10 \%$ trichloroacetic acid (TCA) and solubilized in $0.25 \mathrm{~N} \mathrm{NaOH}$ at room temperature. Cell associated radioactivity was determined by liquid scintillation counting (15).

Iodination and degradation of lipoproteins. Lipoproteins were iodinated with $\mathrm{Na}^{125} \mathrm{I}(17 \mathrm{Ci} / \mathrm{mg}$ in $0.1 \mathrm{~N} \mathrm{NaOH})$ using the iodine monochloride injection method of McFarlane (24). Thin layer chromatographic separation and quantification of iodinated lipoprotein metabolic breakdown products (mono- and diiodotyrosine and iodide) was performed using the method of Chisolm et al. (25).

$\left[{ }^{3} \mathrm{H}\right]$ Leucine incorporation into proteins. Protein synthesis was monitored by measuring $\left[{ }^{3} \mathrm{H}\right.$ ] leucine incorporation into TCA precipitable material from the cell layer and media. Cells were incubated with $\left[{ }^{3} \mathrm{H}\right]$ leucine $(1 \mu \mathrm{Ci} / \mathrm{ml})$ for varying periods and were then washed four times with ice cold 5\% TCA. The precipitated material was resuspended in $0.25 \mathrm{~N} \mathrm{NaOH}$ for at least $10 \mathrm{~min}$. Aliquots were removed and assayed for radioactivity by liquid scintillation counting.

Cholesterol loading of fibroblasts. Cells were pretreated with albumin: cholesterol coacervates as previously described $(26,27)$ for $1.5 \mathrm{~h}$ before adding toxins or control media. Total cellular cholesterol, was measured as above after trypsinizing and pooling cells from three replicate wells of treated and untreated cells. Total cell cholesterol increased $>2.5$-fold.

\section{Results}

Lysosomal enzyme inhibitors. We first asked whether lysosomal degradation of oxidized LDL is required for oxidized LDL induced cell death pathway. Oxidized LDL could hypothetically be transformed by lysosomal enzymes to a toxic molecule and subsequently cause cell death. We employed nontoxic concentrations of the lysosomal enzyme inhibitors chloroquine (25 $\mu \mathrm{M})$ and ammonium chloride $(10 \mathrm{mM})$. At these concentrations the agents inhibited the lysosomal protein degradation by $>90 \%$ using native LDL as an indicator; however no protection against oxidized LDL induced cytotoxicity was found.

Interference with cellular cholesterol metabolism. Particular oxysterols have been shown to interfere with cellular cholesterol metabolism and for some, this interference leads to cell death that can be inhibited by supplying the cell with unoxidized free cholesterol (28). Since cell injury by oxidized LDL had been linked to oxysterols $(16,29)$, we determined whether supplying exogenous cholesterol to cells would inhibit oxidized LDL toxicity. Marked increases in total cell cholesterol, achieved by pretreatment with cholesterol-albumin coacervates, did not inhibit toxicity.

Ebselen: a seleno-peroxidase mimetic. It has been reported that the synthetic seleno-organic compound Ebselen has lipid hydroperoxide-reducing activity (30) and in light of our finding that $7 \beta-\mathrm{OOH}$ chol is the major oxidized LDL-borne cytotoxin (16), we examined whether Ebselen protects against oxidized LDL induced cell death in human fibroblast cells. Fig. $1 A$ and $B$ display the significant protection by Ebselen against both oxidized LDL and $7 \beta-\mathrm{OOH}$ chol induced cytotoxicity.

Inhibitors of arachidonic acid metabolism. Ebselen has other effects, including lipoxygenase inhibiting properties (31). As a result, arachidonic acid metabolism inhibitors were examined to clarify whether arachidonic acid metabolites play a role in oxidized LDL induced cytotoxicity. ETYA $(10-60 \mu \mathrm{M})$, 

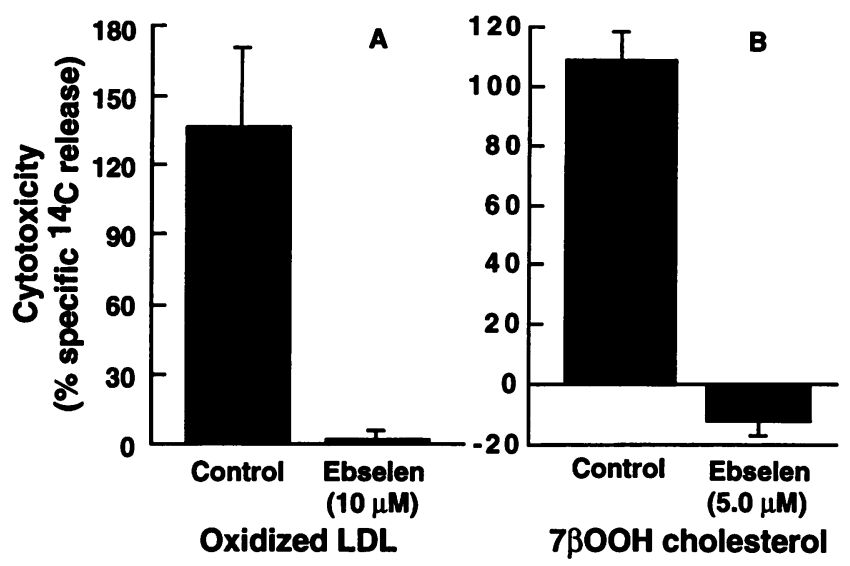

Figure 1. The effect of Ebselen on oxidized LDL and $7 \beta-\mathrm{OOH}$ chol induced cytotoxicity to fibroblasts. Fibroblasts, synchronized by double thymidine block $(A)$, were pretreated with $0.5 \%$ DMSO (Control) or $10 \mu \mathrm{M}$ Ebselen in $0.5 \%$ DMSO for $10 \mathrm{~h}$ and then released from the second thymidine block and exposed to oxidized LDL ( $300 \mu \mathrm{g}$ cholesterol $/ \mathrm{ml}$ ) in the presence of $0.5 \%$ DMSO (Control) or $10 \mu \mathrm{M}$ Ebselen in $0.5 \%$ DMSO. In a separate experiment $(B)$ freely growing fibroblasts were exposed to $7 \beta-\mathrm{OOH}$ chol $(0.5 \mu \mathrm{g} / \mathrm{ml})$ in cultures containing $0.1 \%$ DMSO (Control) or $10 \mu \mathrm{M}$ Ebselen in $0.1 \%$ DMSO. Cytotoxicity was assayed by measuring specific ${ }^{14} \mathrm{C}$ release into the media after preloading cells with $\left[{ }^{14} \mathrm{C}\right]$ adenine as described (see Methods).

and cyclooxygenase inhibitors, indomethacin (10-80 $\mu \mathrm{M})$ and acetylsalicylic acid $(10-80 \mu \mathrm{M})$, were used both as pretreatment and as treatment concurrent with lipoprotein incubation. None of these agents inhibited the cytotoxicity of oxidized LDL (data not shown). Other putatively specific lipoxygenase inhibitors were not used, since most have been shown to be metal ion chelators or nonspecific antioxidants $(32,33)$. These data were consistent with Ebselen acting through the cellular breakdown of a toxic lipid hydroperoxide carried by oxidized LDL or formed in cells after exposure to oxidized LDL, and suggested a hydroperoxide-dependent mechanism of cell death.

Effects of metal ion chelation and iron loading on oxidized $L D L$ induced cytotoxicity. Transition metals are implicated in multiple cell damaging oxidative pathways, such as the HaberWeiss reaction, the induction of single-strand breaks in DNA, and the propagation of lipid peroxidation $(34,35)$. We examined multiple metal chelators believed to be active intracellularly in an attempt to ascertain whether cellular metal ions play a role in oxidized LDL induced cell death. One to $50 \mathrm{mM}$ pretreatments with Desferal, a well known iron chelator (36), inhibited oxidized LDL induced toxicity significantly (data not shown). In addition, we found that pretreatment with $3 \mathrm{mM}$ Desferal protected fibroblasts from the oxidized LDL-borne cytotoxin, $7 \beta-\mathrm{OOH}$ chol (data not shown).

Because Desferal is known to have other cellular effects (37), Tiron, a well-characterized chelator of intracellular transition metal ions (38), was also tested. Fig. $2 A$ reveals that pretreatment with Tiron protected fibroblasts in a concentration dependent fashion. Pretreatment with Tiron $(10 \mathrm{mM})$ also protected cells against $7 \beta-\mathrm{OOH}$ chol induced injury as seen in Fig. 2 B. 1,10-Phenanthroline, another metal chelator shown to be active intracellularly (39), was tested and also showed significant protection against oxidized LDL induced cytotoxicity at a $100 \mu \mathrm{M}$ concentration, but only when employed as a treatment concurrent with oxidized LDL exposure as seen in Fig. $3 \mathrm{~A}$.
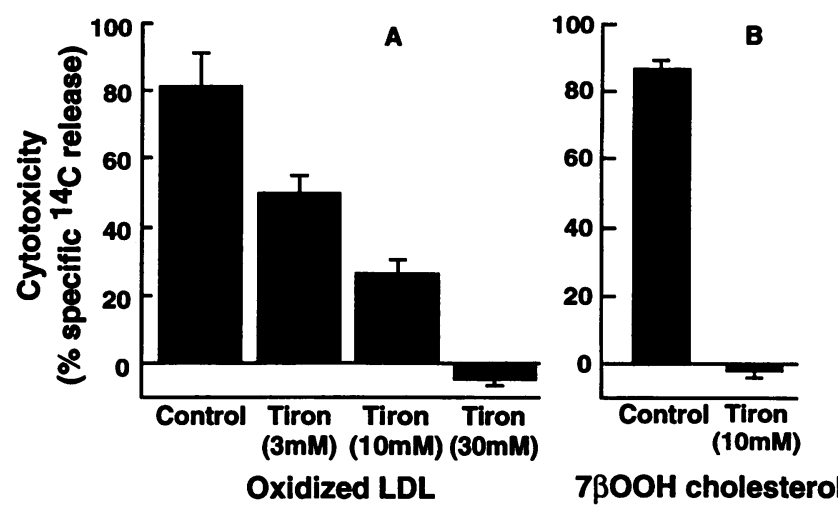

Figure 2. The effect of Tiron on oxidized LDL and $7 \beta-\mathrm{OOH}$ chol induced cytotoxicity. Fibroblasts were synchronized using a double thymidine block (see Methods). During the second thymidine block, various concentrations of Tiron dissolved in media were added to the cells. The cells were released from the second thymidine block and either oxidized LDL ( $250 \mu \mathrm{g}$ cholesterol $/ \mathrm{ml})(A)$, or $7 \beta-\mathrm{OOH}$ chol $(1.46 \mu \mathrm{g} /$ $\mathrm{ml}$ ) in acetone/ethanol ( $0.5 \%$ final concentration) or solvent alone, was added $(B)$. Cytotoxicity was assayed by measuring specific ${ }^{14} \mathrm{C}$ release into the media as described (see Methods).

(Pretreatment with higher concentrations, e.g., $150 \mu \mathrm{M}$, was toxic to cells $) .1,10$-Phenanthroline $(75 \mu \mathrm{M})$ likewise protected fibroblasts from $7 \beta-\mathrm{OOH}$ chol when employed as a concurrent treatment (see Fig. $3 B$ ).

Using an alternate approach, we attempted to clarify further the role of intracellular iron in oxidized LDL induced cytotoxicity by preloading fibroblasts with iron and then exposing them to sublethal concentrations of oxidized LDL or $7 \beta-\mathrm{OOH}$ chol. Specifically, we pretreated the fibroblasts with $10 \mu \mathrm{M}$ ferric ammonium citrate and $2 \mathrm{mM}$ 8-hydroxyquinoline as described (40). Fig. $4 A$ and $B$ show that the iron preloaded cells were significantly more susceptible to injury compared to the untreated control group. In the experiment shown, $125 \mu \mathrm{M}$ DTPA
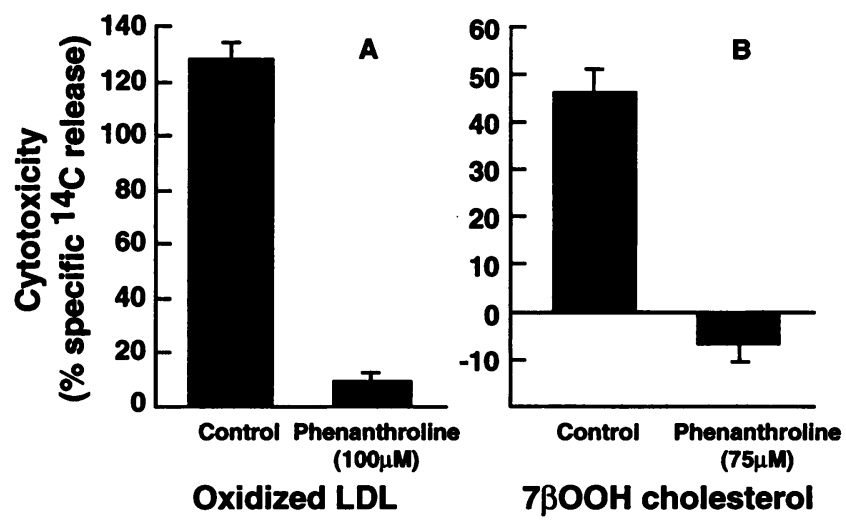

Figure 3. The effect of 1,10-phenanthroline on oxidized LDL and $7 \beta$ $\mathrm{OOH}$ chol induced cytotoxicity. Fibroblasts were synchronized using a double thymidine block (see Methods). The cells were released from the second thymidine block and either 1,10 -phenanthroline in $0.5 \%$ ethanol or $0.5 \%$ ethanol ( Control) was added. $1 \mathrm{~h}$ later either oxidized LDL $(50 \mu \mathrm{g}$ cholesterol $/ \mathrm{ml})(A)$, or $7 \beta-\mathrm{OOH}$ chol $(1.24 \mu \mathrm{g} / \mathrm{ml})$ in acetone/ethanol or solvent alone $(0.5 \%$ each, final concentration $)(B)$ was added to the cells. Cytotoxicity was assayed by measuring specific ${ }^{14} \mathrm{C}$ release into the media as described (see Methods). 

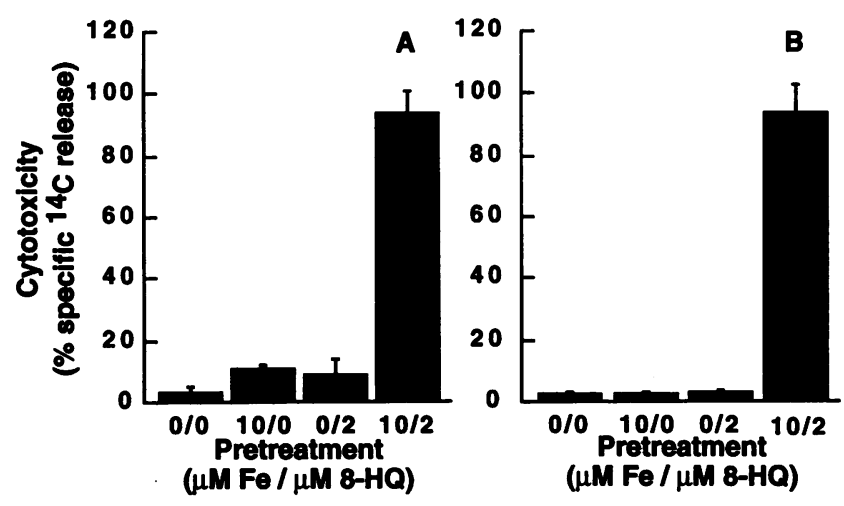

Figure 4. Alterations in fibroblast response to sublethal concentrations of oxidized LDL after loading cells with iron. Fibroblasts were synchronized using a double thymidine block ( see Methods). The cells were released from the second thymidine block and incubated in Dulbecco's PBS containing $1 \mathrm{mg} / \mathrm{ml}$ glucose and $125 \mu \mathrm{M}$ DTPA with various combinations of $10 \mu \mathrm{M}$ ferric ammonium citrate and or $2 \mu \mathrm{M}$ 8-hydroxyquinoline ( $8-\mathrm{HQ}$ ) in $0.1 \%$ ethanol for $40 \mathrm{~min}$. The cells were washed and either $20 \mu \mathrm{g}$ cholesterol $/ \mathrm{ml}$ oxidized LDL $(A)$ or $0.5 \mu \mathrm{g} / \mathrm{ml} 7 \beta$ $\mathrm{OOH}$ chol $(B)$ was added in DME. Twenty hours later cytotoxicity was assayed by measuring specific ${ }^{14} \mathrm{C}$ release into the media as described (see Methods).

was added with the toxins to lessen the possibility that iron released from the iron loaded cells might oxidize LDL further, increasing its toxicity. Identical results were obtained in the absence of DTPA. Two metal chelators that are active extracellularly, DTPA (0.1-1 mM) and EDTA (0.1-0.3 mM), showed no protection in the absence of iron loading (data not shown).

The potential roles of superoxide anion, singlet oxygen, hydrogen peroxide, and hydroxyl radical. We used several free radical scavengers known to scavenge superoxide anion intracellularly in an attempt to clarify whether superoxide participates in oxidized LDL induced cell death. Superoxide dismutase conjugated with polyethylene glycol (SOD-PEG, $3500 \mathrm{U} / \mathrm{ml}$ ), and $\mathrm{Cu}$-3,5-diisopropylsalicylic acid (25 to $100 \mu \mathrm{M}$ ) did not offer any protection against cell death at concentrations demonstrated by others to be effective scavengers in various cell systems $(41,42)$. Moreover, the xanthine oxidase inhibitor, allopurinol $(0.1-0.3 \mathrm{mg} / \mathrm{ml})$, showed no protection against oxidized LDL induced cytotoxicity (data not shown).

An attempt was also made to determine whether hydroxyl radical $(\cdot \mathrm{OH})$, a product of the Haber-Weiss reaction, was involved in the death mechanism. The $\cdot \mathrm{OH}$ scavengers, mannitol ( $20-40 \mathrm{mM}$ ), DMSO ( 1 to $2 \%$ by volume), and tryptophan (1.0-5 $\mathrm{mM}$ ), offered no protection against oxidized LDL induced cytotoxicity (data not shown). Histidine (1-40 mM), reported to scavenge both hydroxyl radical and singlet oxygen (43), was likewise ineffective as an inhibitor.

A possible role for hydrogen peroxide was also examined. Several experiments using catalase $(0.03-1 \mu \mathrm{M})$ were performed in which no protection was observed. (Catalase at concentrations of above $0.3 \mu \mathrm{M}$ or above inhibited fibroblast proliferation; data not shown). In an alternate approach, poly (ADPribose) polymerase inhibitors were utilized to examine whether an increase in poly (ADP-ribose) polymerase activity secondary to DNA damage was involved in oxidized LDL induced cytotoxicity, as has been documented for $\mathrm{H}_{2} \mathrm{O}_{2}$-induced cell death $(44,45)$. Specifically, 3-aminobenzamide $(2-50 \mathrm{mM})$, nicotin-

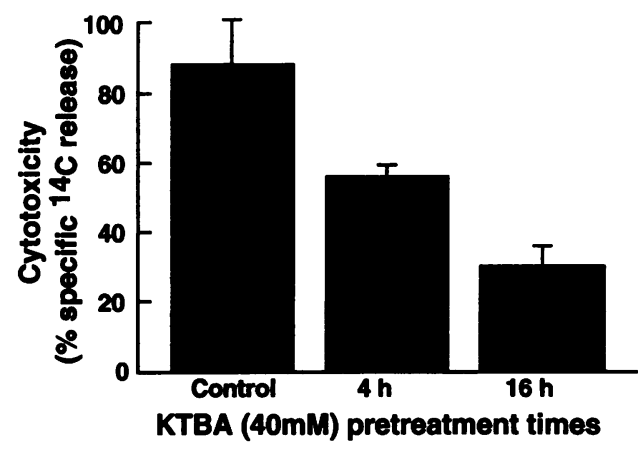

Figure 5. The effect of pretreatment with KTBA on the toxicity of oxidized LDL. Fibroblasts were synchronized using a double thymidine block (see Methods). During the second thymidine block, $40 \mathrm{mM}$ KTBA dissolved in media was added for various times. The cells were released from the block and oxidized LDL ( $250 \mu \mathrm{g}$ cholesterol $/ \mathrm{ml})$ was added. Cytotoxicity was assayed by measuring specific ${ }^{14} \mathrm{C}$ release into the media as described (see Methods).

amide $(4-8 \mathrm{mM})$, and theophylline $(0.5-6 \mathrm{mM})$ were employed as inhibitors of poly (ADP-ribose) polymerase at doses shown clearly to inhibit $\mathrm{H}_{2} \mathrm{O}_{2}$-mediated cell death in various cell systems (44). The inhibitors offered no protection against oxidized LDL induced cell death (data not shown).

Protein synthesis inhibitors. To investigate whether new protein synthesis was involved in oxidized LDL induced cell death, as may occur in particular instances of programmed cell death (46), we added cycloheximide $(0.15 \mu \mathrm{g} / \mathrm{ml})$ and emetine $(0.06 \mu \mathrm{M})$, following the start of S-phase, after release of cells from the second thymidine block. These agents inhibited protein synthesis by up to $97 \%$, but no protection from oxidized LDL cell death in fibroblasts was observed.

KTBA: a putative scavenger of alkoxyl radical ( $L O \cdot$ ). A possible immediate product of lipid hydroperoxide reduction by metal ions is the alkoxyl radical. The putative alkoxyl radical scavenger 2-keto-4-thiolmethyl butyric acid (KTBA) $(47,48)$ was used to determine whether alkoxyl radicals could be intermediate in the sequence of oxidized LDL induced cytotoxicity. As shown in Fig. 5, $40 \mathrm{mM}$ KTBA pretreatment protected fibroblasts against oxidized LDL. In the same experiment, 10 and $20 \mathrm{mM}$ pretreatments of KTBA for $16 \mathrm{~h}$ also protected cells. These results are consistent with alkoxyl radical participation in the mechanism by which oxidized LDL causes cell death.

Involvement of lipid and lipid peroxyl radicals $(L \cdot$ and $L O O \cdot$ ). Iron-mediated lipid hydroperoxide reduction and alkoxyl radical formation can lead to the production of peroxyl radical (34). Since peroxyl radicals are believed to play a significant role in the propagation of lipid peroxidation (49), we tested potential protection by vitamin $\mathrm{E}$ and probucol, both known to scavenge peroxyl radicals $(50,51)$, and both were protective against cellular injury by oxidized LDL (52), as demonstrated in Fig. 6 and 7. Vitamin E and probucol have the capacity to scavenge alkoxyl and lipid radicals in addition to peroxyl radicals $(49,52)$. Since DPPD has been reported to scavenge lipid and peroxyl radicals (53), we also used this antioxidant to test inhibition. The results in Fig. 8, $A$ and $B$ reveal that pretreatment with DPPD protected fibroblasts from oxidized LDL and $7 \beta-\mathrm{OOH}$ chol induced cell death.

Protection against toxicity of $7 \beta-\mathrm{OOH}$ chol to quiescent cells. The experiments above were generally performed using 


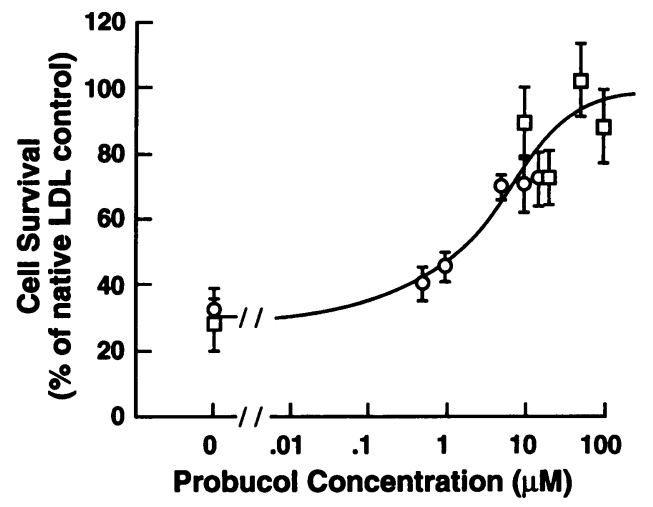

Figure 6. The effect of probucol on oxidized LDL induced cytotoxicity to fibroblasts. This figure represents data derived from two similar experiments. Fibroblasts were synchronized using a double thymidine block (see Methods). During the second thymidine block, either probucol (various concentrations) in $0.5 \%$ DMSO or $0.5 \%$ DMSO (Control) was added to the cells. The cells were released from this block and oxidized LDL ( $150 \mu \mathrm{g}$ cholesterol $/ \mathrm{ml}$ ) was added. Cell survival was assayed by cell enumeration as described (see Methods).

synchronized cells exposed to toxins as they were released into S-phase, the phase of the cell cycle during which we have previously shown markedly enhanced susceptibility to oxidized LDL induced injury (15). However, we also asked whether the inhibitors effective against toxicity to proliferating cells would also inhibit the toxicity to cells that were quiescent. Using the higher concentrations of $7 \beta-\mathrm{OOH}$ chol required to injure quiescent cells $(2-7 \mu \mathrm{g} / \mathrm{ml})$ we found that pretreatment with Ebselen $(1.0 \mu \mathrm{m})$, Desferal (3 mM), Tiron (3 mM), KTBA (40 mM), and DPPD $(0.5 \mu \mathrm{m})$ also inhibited toxicity to cells made quiescent by culturing three days in serum free medium. These results (data not shown) indicate that inhibition by these agents is not secondary to their interference with cell cycle progression.

Control experiments. Several experiments were performed to clarify whether selected inhibitors were protecting against oxidized LDL induced cytotoxicity by a mechanism distinct from the activity for which the inhibitor was chosen for study. We tested whether residual amounts of cell- or substrate-associated inhibitors used as a pretreatment remained available, even after washing the cells, to protect oxidized LDL from further oxidation and thereby only appear to decrease its relative ability

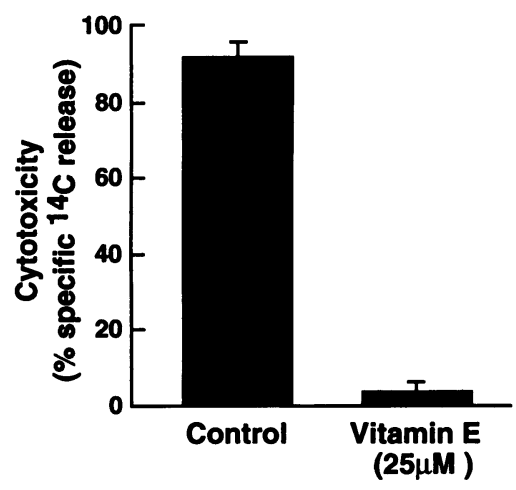

Figure 7. The effect of vitamin $\mathrm{E}$ on oxidized LDL induced cytotoxicity. Fibroblasts were synchronized using a double thymidine block ( see Methods). During the second thymidine block either $25 \mu \mathrm{M}$ vitamin $\mathrm{E}$ in $0.5 \%$ ethanol or $0.5 \%$ ethanol (Control) was added to the cells. The cells were released from this block and oxidized LDL ( $250 \mu \mathrm{g}$ choles-

terol $/ \mathrm{ml}$ ) was added. Cytotoxicity was assayed by measuring specific ${ }^{14} \mathrm{C}$ release into the media as described (see Methods).
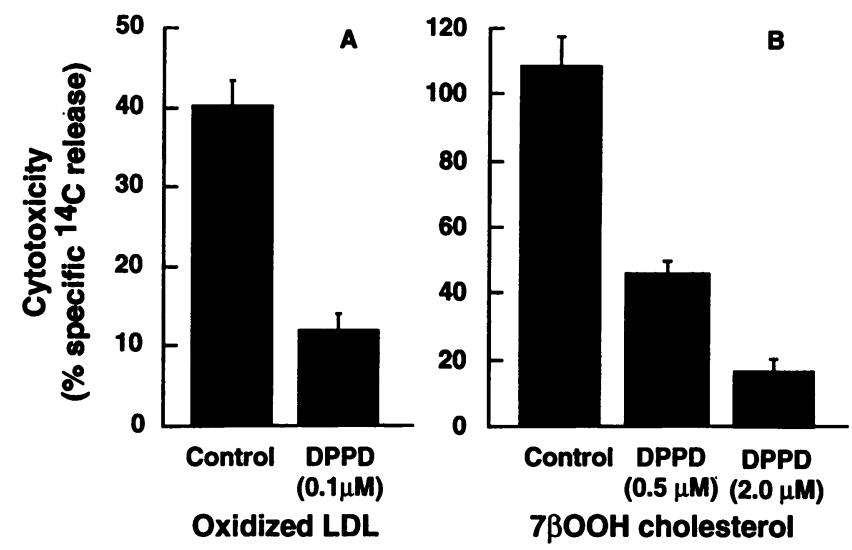

Figure 8. The effect of DPPD on oxidized LDL and $7 \beta-\mathrm{OOH}$ chol induced cytotoxicity. Fibroblasts, synchronized using a double thymidine block $(A)$, were pretreated with either $0.1 \mu \mathrm{M}$ DPPD in $0.5 \%$ DMSO or $0.5 \%$ DMSO (Control) during the second thymidine block. The cells were released from the thymidine block and exposed to oxidized LDL ( $250 \mu \mathrm{g}$ cholesterol/ml) for $20 \mathrm{~h}$. In a separate experiment $(B)$ freely growing (asynchronous) fibroblasts were exposed to $7 \beta$ $\mathrm{OOH}$ chol $(0.5 \mu \mathrm{g} / \mathrm{ml})$ for $24 \mathrm{~h}$ in cultures containing either 0.5 or 2.0 $\mu \mathrm{M}$ DPPD in $0.1 \%$ DMSO or $0.1 \%$ DMSO (Control). Cytotoxicity was assayed by measuring specific ${ }^{14} \mathrm{C}$ release into the media as described ( see Methods).

to injure cells. Specifically, we removed the oxidized LDL containing supernatant that had been incubated with pretreated (vitamin E) and unpretreated fibroblasts and placed it on fresh proliferating fibroblasts to compare the cytotoxicities of the two. The oxidized LDL incubated with the pretreated cells was not less toxic (data not shown).

In another experiment, we prepared oxidized LDL and used a concentration chosen for which we could verify that subsequent oxidation did not further enhance its cytotoxicity. This oxidized LDL was exposed to fibroblasts pretreated with the inhibitors, probucol and DPPD. These inhibitors, employed as pretreatments, protected against this oxidized LDL as well (data not shown). The results indicated that the inhibitors tested were protecting against oxidized LDL induced cytotoxicity by a mechanism other than blocking the further oxidation of LDL. This is consistent with the idea that a pretreatment that successfully inhibited toxicity did so by altering cellular events.

We also considered whether the inhibitors tested afforded protection secondarily by blocking the cellular uptake, processing, or metabolism of oxidized LDL rather than interfering directly with a cell death mechanism. To examine this possibility, we measured radiolabeled oxidized LDL degradation rates under the influence of selected inhibitors. The inhibitors Tiron and probucol, used at concentrations at which they were successful inhibitors of toxicity, did not decrease radiolabeled oxidized LDL degradation (data not shown).

\section{Discussion}

The cellular mechanism involved in oxidized-LDL induced cell death. Ebselen has been reported to reduce hydroperoxides to their corresponding alcohols (54). There have been suggestions by some that Ebselen can also scavenge free radicals (54); however, others show it is not a potent radical scavenger, and its antioxidant capacity does not seem to be related to a free 


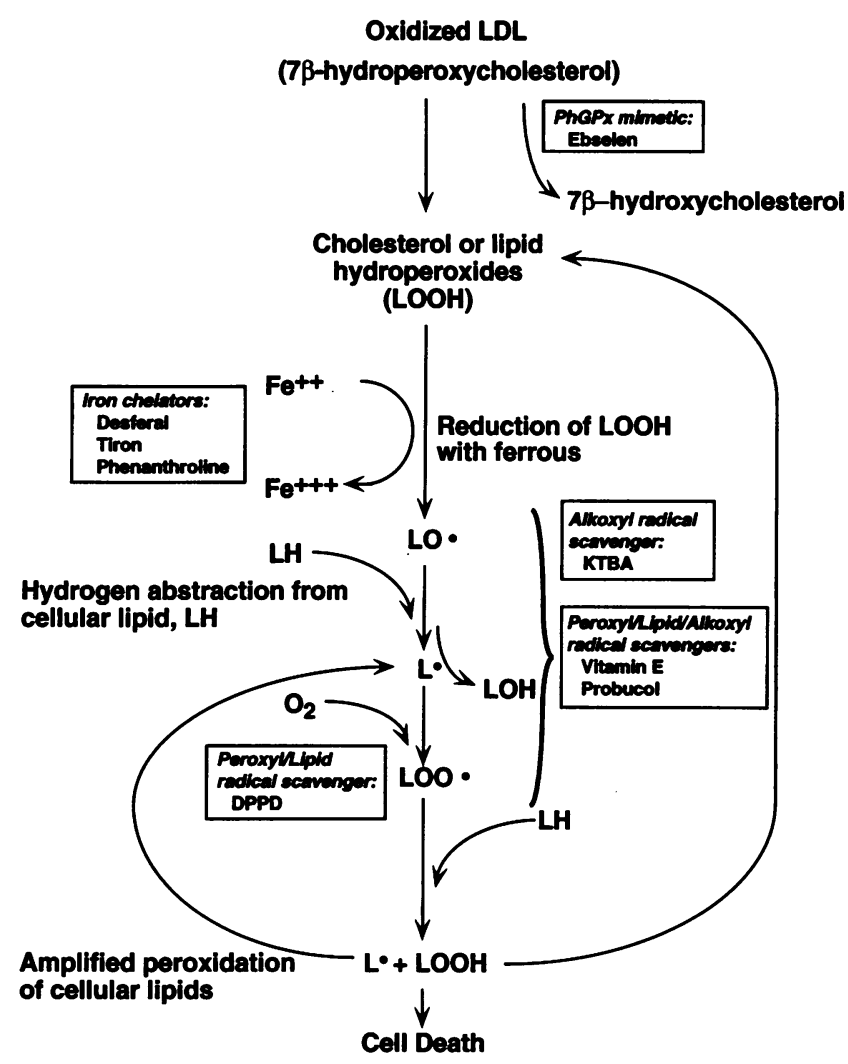

Figure 9. The proposed iron dependent lipid peroxidation pathway of oxidized LDL or $7 \beta-\mathrm{OOH}$ cholesterol induced cytotoxicity involves the formation of alkoxyl radicals, lipid radicals, and peroxyl radicals as intermediates, leading to amplified peroxidative cell injury.

radical scavenging effect $(30,55)$. In addition to its phospholipid hydroperoxide glutathione peroxidase (PhGPx) like activity, Ebselen has been reported to inhibit lipoxygenase (31). Our experiments using inhibitors of arachidonic acid metabolism showed no protection. Maiorino et al. (30) noted that Ebselen showed reactivity not only toward phospholipid hydroperoxides but also toward cholesterol and cholesteryl ester hydroperoxides in membranes and lipoproteins. These findings lead us to speculate that Ebselen protects fibroblasts from oxidized LDL induced death mainly through conversion of toxic lipid hydroperoxides borne by oxidized LDL, or those formed from cellular lipids, to their less toxic alcohols. That Ebselen is protective is consistent with our recent finding that the primary cytotoxin of oxidized LDL is a lipid hydroperoxide, $7 \beta$-hydroperoxycholesterol (16).

To identify further steps in the mechanism of oxidized LDL and $7 \beta-\mathrm{OOH}$ chol toxicity, we examined the role of cellular transition metals, which have been reported to be involved in various oxidant cell damaging pathways, ranging from Fenton and Haber-Wiess reactions to DNA strand breakage (44) to initiation of lipid peroxidation through the formation of alkoxyl radicals (see Fig. 9) (56). Many chelators are not exclusively metal scavengers. Under certain circumstances, Tiron may scavenge $\cdot \mathrm{OH}$, superoxide anion, alkyl, and alkoxyl radicals (38) and Desferal may also quench peroxyl radicals (37). We therefore used multiple intracellularly active metal chelators at various concentrations in an attempt to demonstrate more confidently the transition metal involvement in oxidized LDL in- duced cytotoxicity. Our data show the metal chelators Tiron, Desferal and 1,10-phenanthroline protected cells while EDTA and DTPA, which cannot readily enter cells (47), showed no protection. Furthermore, preloading cells with iron rendered toxic even sublethal concentrations of oxidized LDL. The inhibition we observed is not secondary to the inhibition of cell cycle progression by limiting cellular iron availability as has been reported to occur (57), since Desferal and Tiron inhibited $7 \beta-\mathrm{OOH}$ chol toxicity to quiescent cells. Our findings, taken together, strongly suggest transition metals, namely cellular iron, play a role in oxidized LDL induced cell death.

To understand how iron mediates oxidized LDL cytotoxicity, several metal iron-mediated pathways known to induce cell death were considered. We observed no protection by poly(ADP-ribose) polymerase inhibition, suggesting that DNA strand breakage, as described by Shraufstatter et al. (44) to explain lethal $\mathrm{H}_{2} \mathrm{O}_{2}$ effects on cells, is unlikely. Similarly, our experiments using a hydrogen peroxide scavenger, a singlet oxygen scavenger, superoxide scavengers, and hydroxyl radical scavengers, many of which scavenge reactants or products of the iron-mediated Fenton and Haber-Weiss reactions, showed no protection. These results suggested that another iron-dependent pathway was involved.

Iron has also been associated with the propagation of lipid peroxidation $(36,38,56)$. Farber and others suggested a relationship between lipid peroxidation and cell death which they observed when hepatocytes were treated with tert-butyl hydroperoxide (34). We used the antioxidants vitamin $\mathrm{E}$ and probucol and both inhibited oxidized LDL toxicity. It has been reported that reactivity with organic peroxyl radicals ( $\mathrm{LOO} \cdot$ ) accounts for most of the antioxidant activity of vitamin E $(49,50)$. Pryor et al. showed that probucol scavenges peroxyl radicals, and they suggested the antioxidant activity of probucol is at least comparable to vitamin E (51). A conclusive statement on the direct relationship between lipid peroxidation and fibroblast cell death cannot be made solely from the protective effects of vita$\min \mathrm{E}$ and probucol, since other radicals (e.g., alkoxyl radical) can also be scavenged by these agents $(58)$. Our results using KTBA, a putative alkoxyl radical scavenger, are consistent with the idea that alkoxyl radicals play a role in oxidized LDL induced cell death. However since alkoxyl radicals are able to induce oxidative cell damage independent of lipid peroxidation (34), protection by vitamin E and probucol could theoretically have been via either inhibition of lipid peroxidation or another alkoxyl-mediated pathway. Consistent with a role for peroxyl radicals are our results showing that pretreatment with DPPD readily protected fibroblasts from oxidized LDL and $7 \beta-\mathrm{OOH}$ chol-induced cytotoxicity. DPPD is reported to scavenge the lipid radicals $\mathrm{L} \cdot$ and $\mathrm{LOO} \cdot$ while not reacting with alkoxyl radicals (53), although we did not independently verify this putative selectivity.

Since the primary cytotoxic fraction of oxidized LDL has been isolated and identified as $7 \beta-\mathrm{OOH}$ chol $(16)$, we tested the effective inhibitors against this compound and found the same inhibitory agents protected fibroblasts from $7 \beta-\mathrm{OOH}$ chol exposure as well. These results were interpreted as further evidence that an intracellular iron dependent lipid peroxidation pathway is the mechanism of oxidized LDL induced cell death. A synopsis of this peroxidation pathway is presented in Fig. 9. We believe our results to be consistent with a role for iron reacting with lipid hydroperoxides of oxidized LDL such as $7 \beta$ hydroperoxycholesterol to form in succession, alkoxyl radicals, 
lipid radicals and peroxyl radicals from cellular lipids. Cell death follows from the amplified peroxidation of cellular lipids shown in Fig. 9. We can only speculate on the origin of the affected cellular lipids. They may come from any cellular lipid pool, including the plasma membrane.

Inherent in a pharmacological study such as this one is the possible occurrence of false positive results (apparent inhibition), due to additional actions of a putative inhibitor, or false negative results, due to its unforeseen inactivation. We have taken several precautions to minimize false interpretations (see Results), including testing selective inhibitors against interference with cell cycle progression, low cellular uptake, poor intracellular distribution, nonoptimal concentrations of the compounds tested, toxicity of the putative inhibitor, or interference with further LDL oxidation during incubation. We shortened the time of exposure of oxidized LDL to cells, we used a metal ion poor cell culture medium to reduce further LDL oxidation, and we used cell pretreatments with putative inhibitors where possible. The compounds and the concentrations we used were selected from published reports which demonstrated the effectiveness of the tested compound in other cell systems and we used multiple inhibitors where available.

Other researchers have studied the inhibition of oxidized LDL-induced cytotoxicity in a variety of cell systems using a number of different types of preparations of oxidized LDL (11). Kuzuya et al. showed that metal ion chelators, vitamin E, and probucol inhibited the toxicity of a particularly toxic variant of oxidized LDL, one in which ferrous or cupric ions remained bound to the oxidized LDL after oxidation $(52,59)$. The similar action of the few inhibitors they used suggests that the mechanism of cell death of their preparation may be analogous to ours and that their metal ion containing preparation of oxidized LDL may act as a carrier of additional metal ion into the cell, serving the same purpose as the cell loading of iron we (Fig. 4) and others achieved using 8-hydroxyquinoline (58).

Negre-Salvayre and coworkers have explored certain aspects of oxidized LDL induced cell death employing LDL oxidized by UV irradiation, which has properties distinct from LDL oxidized by metals, and using a transformed lymphoblast cell line as target cells $(12,60)$. They studied the effectiveness of probucol, vitamin E, and the flavonoids catechin and quercetin, against cytotoxicity induced by UV irradiated LDL (61, 62 ). Their data suggested the flavonoids and vitamin $E$ inhibited toxicity; however, in contradistinction to our results and those of others $(52,58)$, probucol was ineffective $(61)$. This discrepancy may relate to the differences in LDL oxidized by UV irradiation versus metals (see above) or differences in susceptibility of various target cells.

Thomas et al. (58) examined the cytotoxicity of another preparation of oxidized LDL, using photooxidation rather than metal-mediated oxidation. They also used various antioxidants as inhibitors and found that Ebselen, Desferal, butylated hydroxytoluene, and probucol protected bovine aortic endothelial cells against oxidized LDL induced cytotoxicity. Their results were generally consistent with ours but were inconclusive as to whether lipid peroxidation was indeed the cause of cell death or whether cell death involved superoxide ion or was due to another alkoxyl radical-mediated pathway, such as DNA or protein damage (34). Our data using the intracellular superoxide scavengers, Cu-3,5-diisopropylsalicylic acid and SOD-PEG, suggest a lack of superoxide involvement.

While it is known that oxidized LDL and $7 \beta-\mathrm{OOH}$ chol are found in arterial lesions in vivo, it is unknown whether they play a role in atherosclerosis. LDL at concentrations similar to plasma concentration levels has been found in atherosclerotic lesions $(63,64)$, but the degree to which it is oxidized is unknown. This raises the question of whether these concentrations of oxidized LDL can lead to injury of the endothelium in early atherosclerosis (65) and/or necrosis in late stage plaque formation. The mechanism of oxidized LDL induced cell death we have presented will hopefully lead to a better understanding of the role of oxidized LDL in atherosclerosis, since identification of the radical intermediates suggests various sites of intervention and also suggests intermediates that could be active in the numerous biological functions attributed to oxidized LDL at sublethal concentrations.

\section{Acknowledgments}

The authors are grateful for technical help and advice from Ms. Tracy Podnar and Dr. Diane Morel. Tissue for the isolation of human foreskin fibroblasts was provided by the Clinical Research Center of the Cleveland Metropolitan General Hospital (USPHS \#M01-RR00210).

This study was supported in part by National Institutes of Health grant HL-29582.

\section{References}

1. Chisolm, G. M., and M. S. Penn. 1996. Oxidized lipoproteins and atherosclerosis. In Atherosclerosis and Coronary Disease. V. Fuster, R. Ross, and E. Topol, editors. Raven Press, New York. 129-149. In press.

2. Steinberg, D., S. Parthasarathy, T. E. Carew, J. C. Khoo, and J. L. Witztum. 1989. Beyond cholesterol. Modifications of low-density lipoprotein that increase its atherogenicity. N. Engl. J. Med. 320:915-924.

3. Penn, M. S., and G. M. Chisolm. 1994. Oxidized lipoproteins, altered cell function and atherosclerosis. Atherosclerosis. 108 (Suppl.):S21-S29.

4. Yla-Herttuala, S., W. Palinski, M. E. Rosenfeld, D. Steinberg, and J. L. Witztum. 1990. Lipoproteins in normal and atherosclerotic aorta. Eur. Heart J. 11 (Suppl E):88-99.

5. Hessler, J. R., A. L. Jr. Robertson, and G. M. Chisolm. 1979. LDL-induced cytotoxicity and its inhibition by HDL in human vascular smooth muscle and endothelial cells in culture. Atherosclerosis. 32:213-229.

6. Hessler, J. R., D. W. Morel, L. J. Lewis, and G. M. Chisolm. 1983. Lipoprotein oxidation and lipoprotein-induced cytotoxicity. Arteriosclerosis. 3:215-222.

7. Morel, D. W., J. R. Hessler, and G. M. Chisolm. 1983. Low density lipoprotein cytotoxicity induced by free radical peroxidation of lipid. J. Lipid Res. 24:1070-1076.

8. Henriksen, T., S. A. Evensen, and B. Carlander. 1979. Injury to human endothelial cells in culture induced by low density lipoproteins. Scand. J. Clin. Lab. Invest. 39:361-368.

9. Jurgens, G., H. F. Hoff, G. M. Chisolm, and H. Esterbauer. 1987. Modification of human serum low density lipoprotein by oxidation - characterization and pathophysiologic implications. Chem. Phys. Lipids 45:315-336.

10. Chisolm, G. M. 1992. The oxidation of lipoproteins: implications for atherosclerosis. In Biological Consequences of Oxidative Stress: Implications for Cardiovascular Disease and Carcinogenesis. L. Spatz and A. D. Bloom, editors. Oxford University Press, New York, New York. 78-106.

11. Chisolm, G. M. 1991. Cytotoxicity of oxidized lipoproteins. Curr. Opin Lipidol. 2:311-316.

12. Negre-Salvayre, A., M. Lopez, T. Levade, M.-T. Pieraggi, N. Dousset, L. Douste-Blazy, and R. Salvayre. 1990. Ultraviolet-treated lipoproteins as a mode system for the study of the biological effects of lipid peroxides on cultured cell II. Uptake and cytotoxicity of ultraviolet-treated LDL on lymphoid cell lines. Biochim. Biophys. Acta. 1045:224-232.

13. Henriksen, T., S. A. Evensen, and B. Carlander. 1979. Injury to cultured endothelial cells induced by low density lipoproteins: protection by high density lipoproteins. Scand. J. Clin. Lab. Invest. 39:369-75.

14. Borsum, T., B. Henriksen, B. Carlander, and A. Reisvaag. 1982. Injury to human cells in culture induced by low density lipoprotein: an effect independent of receptor binding and endocytotic uptake of low density lipoprotein. Scand. J. Clin. Lab. Invest. 42:75-81

15. Kosugi, K., D. W. Morel, P. E. DiCorleto, and G. M. Chisolm. 1987 Toxicity of oxidized low-density lipoprotein to cultured fibroblasts is selective for S phase of the cell cycle. J. Cell. Physiol. 130:311-320. 
16. Chisolm, G. M., G. Ma, K. C. Irwin, L. L. Martin, K. G. Gunderson, L. F. Linberg, D. W. Morel, and P. E. DiCorleto. 1994. $7 \beta$-hydroperoxycholest-5-en$3 \beta$-ol, a component of human atherosclerotic lesions, is the primary cytotoxin of oxidized human low density lipoprotein. Proc. Natl. Acad. Sci. USA. 91:1145211456.

17. Hatch, F. T. and R. S. Lees. 1968. Practical methods for plasma lipoprotein analysis. Adv. Lipid Res. 6:1-68.

18. Lowry, O. H., N. J. Rosenbrough, A. L. Farr, and R. J. Randall. 1951. Protein measurement with the Folin phenol reagent. J. Biol. Chem. 193:265-275.

19. Schuh, J., G. F. Fairclough, and R. H. Haschemeyer. 1978. Oxygenmediated heterogeneity of apo-low-density lipoprotein. Proc. Natl. Acad. Sci. USA. 75:3173-3177.

20. Freeman, M., Y. Ekkel, L. Rohrer, M. Penman, N. J. Freedman, G. M. Chisolm, and M. Krieger. 1991. Expression of type I and type II bovine scavenge receptors in Chinese hamster ovary cells: Lipid droplet accumulation and nonreciprocal cross competition by acetylated and oxidized low density lipoprotein. Proc. Natl. Acad. Sci. USA. 88:4931-4935.

21. Hamilton, T. A., G. P. Ma, and G. M. Chisolm. 1990. Oxidized low density lipoprotein suppresses the expression of tumor necrosis factor-alpha mRNA in stimulated murine peritoneal macrophages. J. Immunol. 144:2343-2350.

22. Roussillon, S., M. Astruc, R. Defay, C. Tabacik, B. Descomos, and A. Crastes de Paulet. 1983. DNA and cholesterol biosynthesis in synchronized embrionic rat fibroblasts. I. Temporal relationships between HMG-Co A reductase activity, sterol biosynthesis and thymidine incorporation into DNA. Biochim. Biophys. Acta. 763:1-10.

23. Shirhatti, V., and G. Krishna. 1985. A simple and sensitive method for monitoring drug-induced cell injury in cultured cells. Anal. Biochem. 147:410418.

24. McFarlane, A. S. 1958. Efficient trace labelling of proteins with iodine. Nature (Lond.). 182:53

25. Chisolm, G. M., C. A. Sila, and S. P. Hmiel. 1981. Measurements of the degradation products of radioiodinated proteins. Anal Biochem. 111.212-219.

26. Fox, P. L., G. M. Chisolm, and P. E. DiCorleto. 1987. Lipoprotein mediated inhibition of endothelial cell production of platelet-derived growth factorlike proteins depends on free radical lipid peroxidation. J. Biol. Chem. 262:60466054

27. Werb, Z., and Z. A. Cohn. 1972. Cholesterol metabolism in the macrophage. 3. Ingestion and intracellular fate of cholesterol and cholesterol esters. $J$. Exp. Med. 135:21-44.

28. Brown, M. S., and J. L. Goldstein. 1974. Suppression of 3-hydroxy3 methylglutaryl coenzyme A reductase activity and inhibition of growth of human fibroblasts by 7-ketocholesterol. J. Biol. Chem. 249:7306-7314.

29. Hughes, H., B. Mathews, M. L. Lenz, and J. R. Guyton. 1994. Cytotoxicity of oxidized LDL to porcine aortic smooth muscle cells is associated with the oxysterols 7-ketocholesterol and 7-hydroxycholesterol. Arterioscler. Thromb. 14:1177-1185.

30. Maiorino, M., A. Roveri, and Ursini. 1992. Antioxidant effects of Ebselen (PZ 51): peroxidase mimetic activity on phospholipid and cholesterol hydroperoxides vs free radical scavenger activity. Arch. Biochem. Biophys. 295:404-409.

31. Safayhi, H., G. Tiegs, and A. Wendel. 1985. A novel biologically active seleno-organic compound-V Inhibition by ebselen (PZ51) of rat peritoneal neutrophil lipoxygenase. Biochem. Pharmacol. 34:2691-2694.

32. McNally, A. K., G. M. Chisolm, D. W. Morel, and M. K. Cathcart. 1990 Activated human monocytes oxidize low-density lipoprotein by a lipoxygenasedependent pathway. J. Immunol. 145:254-259.

33. Parthasarathy, S., E. Wieland, and D. Steinberg. 1989. A role for endothelial cell lipoxygenase in the oxidative modification of low density lipoprotein. Proc. Natl. Acad. Sci. USA. 86:1046-1050.

34. Farber, J. L., M. E. Kyle, and J. B. Coleman. 1990. Mechanisms of cell injury by activated oxygen species. Lab. Invest. 62:670-679.

35. Dix, T. A., and J. Aikens. 1993. Mechanism and biological relevance of lipid peroxidation initiation. Chem. Res. Toxicol. 6:2-18.

36. Halliwell, B., and J. M. C. Gutteridge. 1984. Oxygen toxicity, oxygen radicals, transition metals and disease. Biochem. J. 219:1-14.

37. Morel, I., J. Cillard, G. Lescoat, O. Sergent, N. Pasdeloup, A. N. Ocaktan, M. A. Abdallah, P. Brissot, and P. Cillard. 1992. Antioxidant and free radica scavenging activities of the iron chelators pyoverdin and hydroxypyrid-4-ones in iron-loading hepatocytic cultures: comparison of their mechanism of protection with that of desferrioxamine. Free Radic. Biol. Med. 13(5):499-508.

38. Krishna, C. M., J. E. Liebmann, D. Kaufman, W. DeGraff, S. M. Hahn, T. McMurry, J. B. Mitchell, and A. Russo. 1992. A catecholic metal sequestering agent 1,2-dihydroxybenzene-3,5-disulfonate confers protection against oxidative cell damage. Arch. Biochem. Biophys. 294( 1):98-106.

39. Hiraishi, H., N. Yajima, N. Yamaguchi, M. Ishida, Y. Katoh, T. Harada, A. Terano, and K. J. Ivey. 1994. Antioxidant protection against oxidant-induced damage in cultured gastric mucosal cells. Gastroenterol. Jpn. 28 Suppl 5:132138

40. Balla, G., G. M. Vercellotti, J. W. Eaton, and H. S. Jacob. 1990. Iron loading of endothelial cells augments oxidant damage. J. Lab. Clin. Med. 116:546-554.

41. Leuthauer, S. W. C., L. W. Oberly, T. D. Oberly, J. R. Sorenson, and K. Ramakrishna. 1981. Antitumor effect of a copper coordination compound with superoxide dismutase-like activity. J. Natl. Cancer Inst. 66:1077.

42. Kensler, T. W., D. M. Bush, and W. J. Kozumbo. 1983. Inhibition of tumor promotion by a biomimetic superoxide dismutase. Science (Wash. DC). $221: 75$

43. Kukreja, R. C., K. E. Loesser, A. A. Kearns, S. A. Naseem, and M. L. Hess. 1993. Protective effects of histidine during ischemic-reprofusion in isolated perfused rat hearts. Am. J. Physiol. 264:H1370-H1381.

44. Schraufstatter, I. U., P. A. Hyslop, D. B. Hinshaw, R. G. Spagg, L. A. Sklar, and C. G. Cochrane. 1986. Hydrogen peroxide- induced injury of cells and its prevention by inhibitors of poly (ADP-ribose) polymerase. Proc. Natl. Acad. Sci. USA. 83:4908-4912.

45. Yamamoto, K., K. Tsukidate, and J. L. Farber. 1993. Differing effects of the inhibition of poly (ADP-ribose) polymerase on the course of oxidant cell injury in hepatocytes and fibroblasts. Biochem. Pharmacol. 46(3):483-491.

46. Sen, S. 1992. Programmed cell death: concept, mechanism and control. Biol. Rev. Camb. Philos. Soc. 67(3):287-319.

47. Halliwell, B., and J. M. C. Gutteridge. 1989. Free radicals in biology and medicine. Clarendon Press, Oxford. 236.

48. Winston, G. W., W. Harvey, L. Berl, and A. I. Cederbaum. 1983. The generation of hydroxyl and alkoxyl radicals from the interaction of ferrous bipyridyl with peroxides. Biochem. J. 216:415-421.

49. Liebler, D. C. 1993. The role of metabolism in the antioxidant function of vitamin E. Crit. Rev. Toxicol. 23(2):147-169.

50. Sies, H., H. Stahl, and A. R. Sundquist. 1992. Antioxidant functions of vitamins E and C, beta-carotine, and other carotenoids. Ann. NY Acad. Sci. 669:720.

51. Pryor, W. A., T. Strickland, and D. F. Church. 1988. Comparison of the efficiencies of several natural and synthetic antioxidants in aqueous sodium dodecyl sulfate micelle solutions. J. Am. Chem. Soc. 110:2224-2229.

52. Kuzuya, M., M. Naito, C. Funaki, T. Hayashi, K. Asai, and F. Kuzuya. 1991. Probucol prevents oxidative injury to endothelial cells. J. Lipid Res. 32:197-204.

53. Masaki, N., M. E. Kyle, and J. L. Farber. 1989. tert-Butyl hydroperoxide kills cultured hepatocytes by peroxidizing membrane lipids. Arch. Biochem. Biophys. 269:390-399.

54. Sies, H. 1993. Ebselen, a selenoorganic compound as glutatione peroxidase mimic. Free Rad. Biol. Med. 14:313-323.

55. Noguchi, O., Y. Yoshida, H. Kaneda, Yamamoto, Y. and E. Niki. 1992. Action of ebselen as an antioxidant against lipid peroxidation. Biochem. Pharmacol. 44:39-44.

56. Minotti, G. 1993. Sources and role of iron in lipid peroxidation. Chem. Res. Toxicol. 6:134-146.

57. Klausner, R. D., T. A. Rouault, and J. B. Harford. 1993. Regulating the fate of mRNA: the control of cellular iron metabolism. Cell. 72:19-28.

58. Thomas, J. P., P. G. Geiger, and A. W. Girotti. 1993. Lethal damage to endothelial cells by oxidized low density lipoprotein: role of selenoperoxidases in cytoprotection against lipid hydroperoxide- and iron-mediated reactions. $J$. Lipid Res. 34:479-490.

59. Kuzuya, M., M. Naito, K. Yamada, C. Funaki, T. Hayashi, K. Asai, and F. Kuzuya. 1990. Involvement of intracellular iron in the toxicity of oxidized low density lipoprotein to cultured endothelial cells. Biochem. Int. 22:567-573.

60. Dousset, N., A. Negre-Salvayre, M. Lopez, R. Salvayre, and L. DousteBlazy. 1990. Ultraviolet-treated lipoproteins as a model system for the study of the biological effects of lipid peroxides on cultured cell. I. Chemical modifications of ultraviolet-treated low-density lipoproteins. Biochim. Biophys. Acta. 1045:219 223.

61. Negre-Salvayre, A., Y. Alomar, M. Troly, and R. Salvayre. 1991. Ultraviolet-treated lipoproteins as a model system for the study of the biological effects of lipid peroxides on cultured cells. III. The protective effect of antioxidants (probucol, catechin, vitamin E) against the cytotoxicity of oxidized LDL occurs in two different ways. Biochim. Biophys. Acta. 1096:291-300.

62. Negre-Salvayre, A., and R. Salvayre. 1992. Quercetin prevents the cytotoxicity of oxidized LDL on lymphoid cell lines. Free Rad. Biol. Med. 12:101-106.

63. Smith, E. B., and R. S. Slater. 1972. Relationship between low density lipoprotein in aortic intima and serum lipid levels. Lancet. 1:463-468.

64. Hoff, H. F., and J. W. Gaubatz. 1982. Isolation of a low density lipoprotein from atherosclerotic vascular tissue of WHHL rabbits. Atherosclerosis. 42:272297.

65. Ross, R. 1986. The pathogenesis of atherosclerosis: an update. N. Engl. J. Med. $314: 488-500$ 